УДК [328.181:352/354]:(005.12+31)(477)

JEL Classification: C81, H70

Doi: $10.31767 /$ su. 2(85)2019.02.03

V. M. Semianovskyi,

PhD in Physics and Mathematics, Associated Professor,

Associated Professor of Department of Econometric Disciplines

and Information Technologies,

National Academy of Statistics, Accounting and Audit,

E-mail: vadimc@i.ua

ResearcherID: X-9595-2018,

ORCID: https://orcid.org/0000-0002-5363-6446

\title{
Participation of the Public in State and Local Governance: Principles, Statistics and European Experience for Ukraine
}

Issues of the effective participation and cooperation of the civil society in power bodies have been a central social problem of the globe in the latest times. Although theoretical issues of participatory governance have been well developed and widely implemented, e. g. in business sector, cooperation of Power and Community pose a serious problem in the world and Ukraine in particular. The effectiveness of cooperation between Power and the civil society is downgraded by the issue the current condition of both parties, the quality of their work and their mutual trust. Also, it needs to be born in mind that this problem is a part of the triangle Power Society - Business, and that the external environment has significant impact in the conditions of globalization.

Given the Ukrainian context, it should be considered that the power system here was inherited from the Soviet Union. It is incompatible with the present-day realities, and its reform has been so far ineffective. The data from the State Statistics Service of Ukraine (SSSU) show the vast numbers of officials in local governance and central power bodies, picked up in industry-like administrative departments. The bulky apparatus of public governance being streamlined on the problem solution process in economic industries, social problems, not mentioning the ones of individual humans, can be looked at only before elections.

On the other hand, according to SSSU, Ukraine has a network of rather diverse public organizations, but their total number is small. According to Eurostat, quantitative and qualitative parameters of the civil society in Ukraine lag far behind the European ones. A diversity of goals, weak consolidation of efforts, resources and methods for solving the most important problems are factors complicating the cooperation between Power and Community.

Theoretical and practical aspects of the problem related with cooperation of Power and the civil society have been elaborated in Europe since long. Advanced principles and various technologies for its solution have been proposed and implemented. The first typology of the public participation in form of "public participation staircase" was admittedly made by researcher Sh. R. Arnstein. She broke the staircase into the three levels: non-participation, symbolic participation, public power. To boost the effectiveness of collaborative action, the European community has elaborated the Code of recommended norms for the participation of the public in taking public decisions. In fact, this technology is the standard of cooperation between Power and Community in Europe.

The need for reform of the system for cooperation of power bodies with the civil society in Ukraine by use the European experience of cooperation is substantiated. The issues of goals, principles, methods and phases of cooperation between the power and the society, their advantages and drawbacks are highlighted.

Key words: public authorities, local self-government, civil society, civil society institutions, participatory governance, cooperation, participation.

Introduction. The problem of effective interactions and cooperation between entities has been always important. In the modern world this problem has been aggravating on account of globalization processes, increasing scales of challenges at global and local level. Solutions for a major part of the problems call for collaborative effort and participatory governance of the processes. The term "Participatory Management" denotes the management based on participation of all the entities within a complex system in management decision making. The problem of cooperation between the civil society and the power bodies is a component of this overall problem, which is very acute in the contemporary Ukraine.

Literature review. Theoretical and practical issues of participatory governance have been quite extensively addressed and employed in the business environment [1]. Issues of cooperation between the civil society and the power bodies are carefully

(C) V. M. Semianovskyi, 2019 
analyzed in the global and European literature. The theme of this study was elaborated in research works of foreign scientists: M. Ali, T. Davis, P. Benoliel, M. Pardo del Val. Recently this issue has been subject to increasing attention from domestic scientists: V. Bakumenko, M. Baran., V. Martynenko, V. Hordiienko, L. Usachenko, I. Rudiak, V. Bilorus, N. Lypovska, O. Obolenskyi, Yu. Sharov and others.

The study's goal is to substantiate the need to reform the system for cooperation between the power and the community in Ukraine on the principles of participatory governance, enhanced effectiveness of the power bodies and the civil society, in order to gradually solve complex problems of the contemporary life. The study's objective is to highlight European systems for cooperation between the power and the community, methods and phases of their cooperation, its advantages and drawbacks and the possibilities for implementing the European practices in Ukraine.

Results. Cooperation between the power and the community is a component in the well known triangle of cooperation: Power - Community - Business (Figure 1).

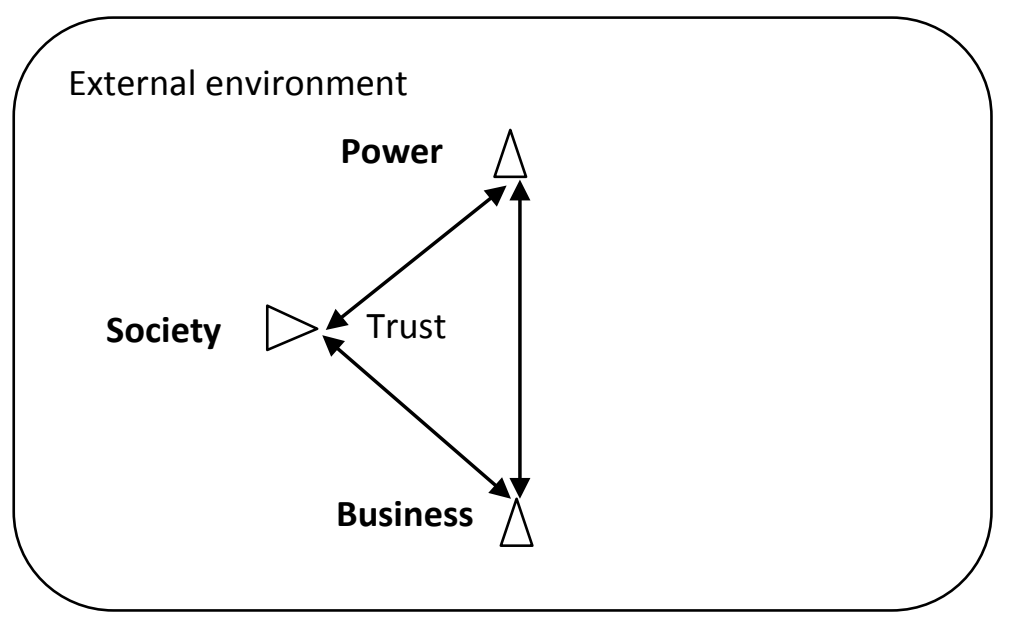

Figure 1. The triangle of cooperation: Power - Society - Business

A study of Power - Community interactions always needs consideration for the other components of the triangle: Business and the external environment. Each component of the triangle is, in its turn, a multicomponent system.

Power - legislative (the Verkhovna Rada of Ukraine, VRU), executive (the Cabinet of Ministers of Ukraine (CMU), President, regional public administrations (RPA), district public administrations (DPA), judicial power and mass media (the 4th power);

Business - big (oligarchs, "local barons" and others), small and medium enterprises, private persons - entrepreneurs.

Community - a large number of various actors of the civil society (individuals, public associations, public organizations, non-profit organizations (NPO), consultative-advisory bodies (CAB) an others).

The main actors with the external impact: The U.S., European countries, and Russia. Trust is an important factor for any kind of activities, especially cooperation.

Cooperation, participation. Cooperation means partnerrelationsbetween two(orseveral)independent parties, joint activities or considerable participation of one party in the other party's activities aimed to achieve a common goal (solve a socially significant problem), by exchanging competencies, technologies and resources. The basis for the cooperation is labor division and trust between the parties. The parties jointly define the essence of a problem, develop a collaborative project for its solution, and share the project risks and results. The parties that act jointly, in the conditions of competition for limited resources, can obtain more resources, produce a better result in a shorter period of time.

A study of cooperation between complex systems needs to consider their structure, functions, peculiarities of operation (rights, obligations, responsibilities) etc. Participation of the civil society in taking and implementing public decisions through cooperation with government institutions has complicated and multi-level character.

The operation of any complex system needs an analysis of its goals and objectives, its legal support, resources, methods, technologies, operation phases, monitoring and analysis of the results.

Power. According to the Ukrainian Constitution, all the power belongs to the people. But practically the people can realize this right via the forms of the short-time democracy: elections and referendums. The permanent agencies of the power's operation are public power bodies and local self-government bodies. 
This is a potent and ramified governance system, considered by the citizens as the real power. On the web-portal of the Cabinet of Ministers of Ukraine, 19 ministries, 2 state services, 14 agencies, 4 inspections, 10 central executive power bodies, 27 local power bodies of the regional level etc. are fixed [2].

The data about the number of public officials and local self-government executives, displayed on the web-site of the State Statistics Service of Ukraine [3], shows that the number of officials has been gradually reducing (see Table 1, compiled by use of data from the State Statistics Service of Ukraine [3]). But the reduction rate is less than the one envisaged in the program of the Statistics Service reforms. It is expected that the number of servants will be considerably decreased once e-government is implemented.

The numbers of public officials and local self-government executives

Table 1 (as of December 31, respective year, persons)

\begin{tabular}{|l|c|c|c|c|c|c|}
\hline \multicolumn{1}{|c|}{ Year } & $\mathbf{2 0 1 0}$ & $\mathbf{2 0 1 1}$ & $\mathbf{2 0 1 2}$ & $\mathbf{2 0 1 3}$ & $\mathbf{2 0 1 4}^{*}$ & $\mathbf{2 0 1 5}^{*}$ \\
\hline Total officials & 379283 & 367308 & 372856 & 433269 & 380257 & 351835 \\
\hline Managers & 115211 & 114741 & 116781 & 130358 & 114740 & 105572 \\
\hline Officials & 264072 & 252567 & 256075 & 302911 & 265517 & 246263 \\
\hline
\end{tabular}

Note: * not counting the temporarily occupied territories.

A very important characteristic is derived by use of the data from the State Statistics Service of Ukraine: 170 residents per a public official in Ukraine. According to the data of Eurostat [4], there are 190 residents per 1 official in France, 163 in Germany, 176 in Belarus, 50 in Estonia, 26 in Latvia, 165 in Lithuania etc. It follows that the number of officials in Ukraine is more or less optimal compared with other countries.

According to the new Law of Ukraine "Public Service" (10.12.2015; hereafter referred to as "Law") [5], the professional public service in Ukraine must rest on new approaches and principles, to assure the European quality of the public governance, enhance the effectiveness of public decision-making for the society's benefit, and open up new opportunities for professional self-realization of public servants.

According to the Constitution of Ukraine (Article 3), the principle duty of the State is to assure and guarantee human rights and freedoms. The State is responsible before a human for its operation. A human, his/her life and health, honor and dignity, untouchability and safety are recognized in Ukraine as the highest social value. But the economic and social condition in Ukraine and the respective international indexes demonstrate that the Ukrainian law is to a large extent ignored (including the Constitution). First and foremost, this is attributed to the extremely low quality of public governance, which to a large extent remains to be bureaucratic and soviet-like, whereas the local self-government does not actually exist.

Therefore, the principal goal of the State (public governance) is to ensure free development of a free human, with observance of his/her rights and freedoms and strict responsibility for their violation. It is a strategic trend in the successful countries of the world. A free and creative human can achieve unique results in the economic and social life not only in his/ her country, but on the global scales (for example, Bill Gates, Elon Musk and others).

A free human is one who is internally free, who freely communicates with other humans, teams, community or society, who freely communicates with Power. A community of free and active citizens makes up the genuinely civil society.

According to the laws of cybernetics, the productivity and quality of project management correlates with close direct links, and especially feedback, in the management system between management actors and the external environment. In a successful country is means a solid system for cooperation between the civil society (Community) andgovernanceinstitutions(Power). Theeffectiveness of such cooperation is determined by the quality of civil society, the quality of public governance and the trust between Community and Power. The quality of civil society and public governance in Ukraine, although agency-specific, is very low in average. This is shown by sociological interviews of the population and conclusions of domestic and international experts. They also emphasize on the extremely low confidence of the society in the power entities.

Civil society (Community). A consolidated society does not exist. A society consists of a great many stakeholders with multiplicity of opinions on issues related to any problem [6]. There are various social actors with impact on the decision making process in power bodies: direct (personal) participation of citizens, public associations, non-profit organizations (NPO), consultative-advisory bodies (CAB) etc. (see Table 2, compiled by data [6] and the Single State Register of Enterprises and Organizations of Ukraine of the State Statistics Services of Ukraine [7]).

Public associations: according to the Ukrainian law, it is voluntary associations of physical persons and/or legal entities of the private law for protecting 
Numbers of public associations in Ukraine

(as of 01 January of the respective year)

\begin{tabular}{|l|c|c|c|c|c|c|}
\hline \multicolumn{1}{|c|}{ Non-government organizations } & $\mathbf{2 0 1 3}$ & $\mathbf{2 0 1 4}$ & $\mathbf{2 0 1 5}^{*}$ & $\mathbf{2 0 1 6}^{*}$ & $\mathbf{2 0 1 7}^{*}$ & $\mathbf{2 0 1 8}^{*}$ \\
\hline Public organizations & 74500 & 77286 & 75828 & 70321 & 75988 & 80461 \\
\hline Unions of citizens' associations & - & - & - & 753 & 990 & 1254 \\
\hline Religious organizations & 24720 & 25475 & 24957 & 23261 & 24072 & 25223 \\
\hline $\begin{array}{l}\text { Trade unions and associations of trade } \\
\text { unions }\end{array}$ & 28852 & 29724 & 28890 & 26321 & 26899 & 27601 \\
\hline $\begin{array}{l}\text { Creative unions (other professional } \\
\text { organizations) }\end{array}$ & 278 & 298 & 277 & - & 292 & 311 \\
\hline Charitable organizations & 14055 & 14999 & 15934 & 15384 & 16837 & 17726 \\
\hline $\begin{array}{l}\text { Associations of co- owners of apart- } \\
\text { ment buildings }\end{array}$ & 15018 & 16213 & 15992 & 17109 & 26080 & 27999 \\
\hline Self- organization bodies & 1426 & 1503 & 1372 & 1415 & 1497 & 1552 \\
\hline
\end{tabular}

Note: * not counting temporarily occupied territories

rights and freedoms, observing public interests: economic, social, cultural, environmental and others.

Non-profit organizations (NPO) can be of various types: consumer cooperatives, public organizations, religions organizations (associations), foundations, establishments, associations of legal entities (associations, unions, concerns etc.).

A consultative-advisory body (CAB) established at power offices is a body created by central power offices, local executive power offices or local selfgovernment bodies to hold consultations, obtain expert opinions or public opinions on issues of concern. The CAB categories cover public councils, collegiums, commissions (permanent, temporary, expert, competitive, supervisory, and accreditation commissions), coordination headquarters, a council (regional, supervisory, consultative, coordinating), a committee (competitive, organizing), a group (working, inter-sectoral working, inter-ministerial commission or council), and a center.

The operation of such bodies is regulated by statutory documents (establishing orders and operative regulations), and they are subordinated to government institutes: departments, divisions, heads of regional public administrations, city majors, head of district public administrations, city councils etc. CAB can have narrow (for solving specific issues) or wide focus (for solving any issues within the competence of a body at which they are established). CAB can initiate sessions to discuss issues and take decisions that are not binding for power bodies. That is why prior to exerting political pressures on power bodies it is desirable to learn what $\mathrm{CAB}$ are established at them (or at their structural units).

The diversified public councils, coordination councils, inter-sectoral working groups or other structures that are established at power bodies either on "permanent" or on "ad hoc" basis are elements of various types of impact (pressure) on power bodies. Their impact cannot be direct, but they can provide recommendations for solving certain issues, and, most importantly, they keep the required issues under review of power bodies.

Public participation. Public participation in taking public decisions is not a separate event, but a process of solving an important problem that has implications for the life of the whole society and its local communities. Public participation enables stakeholders to solve the issues with the highest social significance and solve them in the most effective manner with support and employment of resources available with the civil society. Issues with the highest social significance are identified using special tools like Swiss Barometer. Any process engaging citizens in the decision-making process and accounting for the citizens' contribution in taking decisions can be referred to as public participation in decision-making and strengthening of the civil society.

One does not need to be a CAB member, to have influence on political decisions. According to the $\mathrm{CAB}$ regulations, one can speak at its session, highlighting a problem and the ways for its solution. CAB is obliged to discuss the problem and provide recommendations to the relevant government agency, thus giving an impulse to its solution.

When launching any significant process with public participation, the power will have to collect information from a wide range of stakeholders, which will result in a wide array of opinions, problems and statements. An operative function of a government agency is to balance between these opinions and problems, and ensure effective elaboration and implementation of the decisions taken with public participation for all the people irrespective of the citizenship, nation, race, skin color, sexual orientation or income.

Issues of desirability. Participation of the civil society in the operation of public administration system is necessary for both parties:

- it really helps improve the governance and enhance the performance of Power, as shown by the practices of global and European structures; 
- it helps Community build the long-term capacity to solve complex social problems, as it often has to overcome persisting controversies and misunderstanding;

- it helps build the trust between citizens and persons engaged in decision-making, and between various stakeholders, which is a matter of extremely importance in Ukraine, given the low public trust to power agencies;

- due to public participation, stakeholders can learn meaningful and collaborative ways for communications, settlements of disputes and taking complex decisions. Stakeholders can learn the ways for understanding each other's values and interests and appreciating each other's opinions. Social interests and values can be better grasped by the public, promoting the development of the civil society and the more sustainable democracy;

- positive results of the permanent public participation in taking and implementing the decisions can enhance the stakeholders' capacities required to solve complex social problems. This considerably improves the investment capacities and widens the opportunities for attracting investors to the territories in question.

Principles of public participation. Public work can be high performing and effective, when its underlying principles are observed.

Active and constructive cooperation. Public organizations collect, fix and translate ideas of their members, target groups and concerned citizens to power agencies and learn the latter's opinions. This helps consider for diverse interests in the decisionmaking process, thus improving the stakeholders' ability to negotiate and the quality of long-term initiatives.

Responsibility and transparency. Actions for the social benefit require openness, responsibility, clarity and transparency at all the phases of interactions between public and power bodies.

Independence. NPO must be recognized by power bodies as free and independent actors with the right to perform independently and protect the opinions that are differ from the opinions of power bodies.

Forms of participation. Forms of public participation depend on the potential public impact on decisions. Not all the participation forms are the same. While sometimes the capabilities of public impact may be quite small, in other cases it may be strong. The scopes of this potential impact are a main factor considered in elaborating a successful public participation program.

To be significant, public participation should aim at obtaining public opinion in certain points of the decision-making process on specific issues, where this contribution has enough potential to help in formulating a decision or an action.
Levels of public participation. The choice of a right level of public participation depends on the participation form and the potential public impact on the decisions. These levels include:

- informing of the public through releasing the information on taken decisions, to help people understand the essence of a problem, probable results and implications of its solution;

- consulting the public, to receive their response concerning alternative options of the solution;

- engagement of the public, to make their interests accounted for throughout the decisionmaking process, especially when elaborating decisionmaking criteria and alternatives.

- cooperation with the public in setting the criteria for finding the best decision, taking this decision and monitoring of its implementation;

- delegation of authority through expanding the rights and opportunities of the public in taking and implementing the decisions.

Regulatory and legal framework for public participation. Ukraine has a solid legal framework regulating interactions of the public with central and local power bodies in the decision-making process [8]:

The Constitution of Ukraine;

The Law of Ukraine "Local Self-Governance in Ukraine";

The Law of Ukraine "Information";

The Law of Ukraine "Communications from Citizens";

The Law of Ukraine "Associations of Citizens";

The Law of Ukraine "The Procedure for Coverage of the Operation of State Power Bodies and Local Self-Governance Bodies in Ukraine in Mass Media";

The Decree of President of Ukraine "Promotion of the of Civil Society Development in Ukraine" from February 26, 2016, No 68;

The Directive of the Cabinet of Ministers of Ukraine "Guarantee of Public Participation in Policy Setting and Implementation" from November 3, 2010, No 996;

The Directive of the Cabinet of Ministers of Ukraine "Adoption of the Procedure for Promoting Public Expert Review of the Operation of Executive Power Bodies" from November 5, 2008, No 976;

The Law of Ukraine "Local Public Administrations";

The Regulation on the Public Council at the regional public administration, regional council (model one, according to directives) etc.

However, the legally adopted tools of public impact on political decisions have been underemployed in Ukraine. Today, Ukraine can employ European tools and standards of Power - Community cooperation between.

The rich experience of public participation in taking public decisions and creating the relevant 
regulatory framework has been accumulated by now in Europe; examples of regulatory acts concerned with engagement of the public in the policy setting process are given below:

- Poland. "The law on Socially Useful and Voluntary Work";

- U.K. "The Regulations of the Practice of Consulting with the Public";

- The Netherlands. "The Law on Social Support";

- Denmark. "The Charter of Interactions between the Volunteers' Network and Public Organizations with the Government Sector";

- Estonia. The Conception for the Civil Society Development.

The Estonian Center of Non-Profit Associations and Foundations acted as the initiator of adopting the Conception as part of a project sponsored by the United Nations Development Program. The possible strategies for promoting the Concept were discussed at meetings of Estonian organizations with politicians. Soon after that, "The Memorandum on Cooperation between Political Parties of Estonia and Organizations of Tertiary Sector" was signed. Apart from NGO experts, its text was written with contributions from politicians and scientists. Public discussions of the draft document were wide-scale and active. More than 3000 organizations were invited to participate in making its final version.

Instruments and methods of participation. The participation of citizens in central and local governance processes can be exercised in a variety of ways and by employing various instruments: from traditional referendums to modern high capacity forms of online interactions. The choice of instruments depends on various factors, such as target auditory, goals and available resources. The instruments employed depend on form and level of participation.

The problem of regular practical employment of instruments for Power - Community cooperation has old history in Europe. Admittedly, the first typology of public participation was designed in 1969 by American researcher and public activist, Sh. R. Arnstein [9]. She presented the results of her study in an illustrative way, in form of "Public Participation Staircase". The general notion "public participation" was broken by her into three levels: non-participation, symbolic participation, and public participation (Figure 2, constructed by data from [9]).

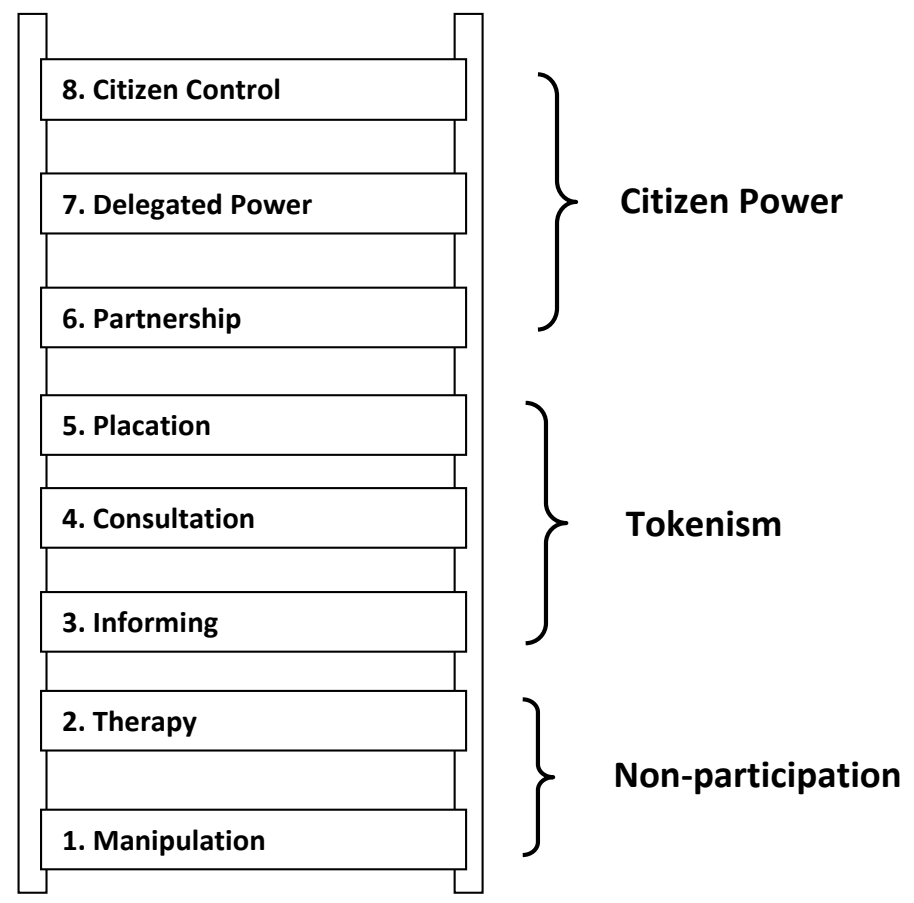

Figure 2. Public Participation Staircase

Non-participation covers the phases of manipulation (1) and psychotherapy (2), employed by power bodies as substitutes for true participation of the civil society.

Symbolic measures (tokenism - uselessness) are the phases of informing (3), consulting (4) and placation (5), by which the power demonstrates that it listens to and hear the public, and that it is willing to consult the public. But the public is not delegated the power authorities, nor is it given the tools for decision-making and control over the proper implementation of taken decisions. The public is not convinced that the situation can be improved.

Citizen Power covers the phases of partnership (co-governance) (6), delegation of authorities (7) and citizen control over the power (8). At the level of power, citizens can carry out negotiations and find compromises, take collective decisions, even receive 
the full governance authority in the areas with public significance.

It is obvious that while the power bodies seek to keep the citizens on lower levels of the staircase, the citizens' objective is to go upstairs. Unfortunately, most part of the public organizations in Ukraine still considers informing and monitoring as their main objectives.

According to Sh. R. Arnstein, public participation is a synonym to public governance. It involves redistribution of power authorities, allowing for the citizens who are now excluded from the majority of political and economic processes to take effective part in them. It is a real means for a serious social reform that will considerably reduce corruption and increase life standards of the population.

It was long ago that the European public understood the difference between formal participation and real power that was required for a real impact on social processes. In May 1968, students of Paris had the slogan: "I participate, you participate, he participates, we participate, you participate..., they have benefit". Participation without power authorities is public's deception.
The system for Power - Community cooperation has been subject to improvements for many years. It was in 1998 that the International Assosiation for Public Participation (IAP2) proposed "The Spectrum of Public Participation" where 5 levels of increase in the civil society impact were distinguished: Informing, Consulting, Involvement, Cooperation, and Delegation of Authority [10]. This scheme was developed with consideration to the opinions of Power and Community at each level of participation.

British researchers G. Rowe and L. Frewer presented "The Typology of Public Involvement Mechanisms" at early 2000s [11]. The typology covered more than one hundred potential instruments for public participation, found in English language literature.

In recent times, the participation system has been widely adopted in UN Sustainable Development Goals [12] and the Code of Recommended Norms for Public Participation in the Decision-Making Process of the Council of Europe [13]. The Code has a sophisticated and multilevel (matrix) structure (see Table 3, constructed by data from [13]).

Table 3

Power and Community: levels and methods of cooperation

\begin{tabular}{|c|c|c|c|c|c|c|}
\hline \multirow{2}{*}{$\begin{array}{c}\text { Level of } \\
\text { participation }\end{array}$} & \multicolumn{6}{|c|}{ Phases of governance decision-making } \\
\hline & 1. Agenda & 2. Documents & 3. Decisions & 4. Implementation & 5. Monitoring & 6. Revision \\
\hline 4. Partnership & $\begin{array}{l}\text { Working } \\
\text { groups, } \\
\text { committees }\end{array}$ & $\begin{array}{l}\text { Joint prepara- } \\
\text { tion of docu- } \\
\text { ments }\end{array}$ & $\begin{array}{l}\text { Joint deci- } \\
\text { sion-making }\end{array}$ & $\begin{array}{l}\text { Strategic partner } \\
\text { links }\end{array}$ & $\begin{array}{l}\text { Working } \\
\text { groups, } \\
\text { committees }\end{array}$ & $\begin{array}{l}\text { Working } \\
\text { groups, } \\
\text { committees }\end{array}$ \\
\hline 3. Dialogue & $\begin{array}{l}\text { Public hear- } \\
\text { ings, forums } \\
\text { of citizens, } \\
\text { essential } \\
\text { contacts } \\
\text { with power } \\
\text { bodies }\end{array}$ & $\begin{array}{l}\text { Public hear- } \\
\text { ings, feedback } \\
\text { groups, expert } \\
\text { seminars, } \\
\text { multilateral } \\
\text { committees, } \\
\text { consultative } \\
\text { bodies }\end{array}$ & $\begin{array}{l}\text { Open plena- } \\
\text { ry sessions, } \\
\text { sessions of } \\
\text { committees }\end{array}$ & $\begin{array}{l}\text { Training seminars, } \\
\text { seminars on capac- } \\
\text { ity building, etc. }\end{array}$ & $\begin{array}{l}\text { Working } \\
\text { groups, } \\
\text { committees }\end{array}$ & $\begin{array}{l}\text { Seminars, } \\
\text { discussion } \\
\text { forums }\end{array}$ \\
\hline 2. Consultations & $\begin{array}{l}\text { Petitions, } \\
\text { online } \\
\text { consulta- } \\
\text { tions }\end{array}$ & $\begin{array}{l}\text { Public hear- } \\
\text { ings, feedback } \\
\text { groups, expert } \\
\text { seminars, } \\
\text { multilateral } \\
\text { committees, } \\
\text { consultative } \\
\text { bodies }\end{array}$ & $\begin{array}{l}\text { Open plena- } \\
\text { ry sessions, } \\
\text { sessions of } \\
\text { committees }\end{array}$ & $\begin{array}{l}\text { Events, confer- } \\
\text { ences, forums, } \\
\text { seminars }\end{array}$ & $\begin{array}{l}\text { Feedback } \\
\text { mechanisms }\end{array}$ & $\begin{array}{l}\text { Conferences, } \\
\text { meetings, } \\
\text { online } \\
\text { consulta- } \\
\text { tions }\end{array}$ \\
\hline 1. Informing & $\begin{array}{l}\text { Open and } \\
\text { easy access } \\
\text { to informa- } \\
\text { tion, studies } \\
\text { of compa- } \\
\text { nies and } \\
\text { lobbying, } \\
\text { websites } \\
\text { with prin- } \\
\text { cipal docu- } \\
\text { ments }\end{array}$ & $\begin{array}{l}\text { Open and } \\
\text { easy access } \\
\text { to informa- } \\
\text { tion, studies } \\
\text { of companies } \\
\text { and lobby- } \\
\text { ing, websites } \\
\text { with principal } \\
\text { documents }\end{array}$ & $\begin{array}{l}\text { Lobbying } \\
\text { companies, } \\
\text { Internet } \\
\text { broadcast- } \\
\text { ing, contri- } \\
\text { butions from } \\
\text { research }\end{array}$ & $\begin{array}{l}\text { Open access to } \\
\text { information, } \\
\text { website with } \\
\text { information access, } \\
\text { e-mail delivery, } \\
\text { public tender pro- } \\
\text { cedures }\end{array}$ & $\begin{array}{l}\text { Open access } \\
\text { to informa- } \\
\text { tion, }\end{array}$ & $\begin{array}{l}\text { Data } \\
\text { collection, } \\
\text { assessments, } \\
\text { research }\end{array}$ \\
\hline
\end{tabular}


The community participation is implemented at various levels of cooperation: informing, consulting, cooperation and delegation of authorities. Six phases of taking and implementing political decisions are distinguished for all the participation forms: developing the agenda; preparing the documents; taking the decision; implementing the decision; monitoring; review. For each level there exist nearly one hundred various instruments for public involvement, which can be employed in interactions of Power and Community.

As regards Ukraine, most part of the domestic public organizations and public activists has wrong feeling that public participation should be limited by ad hoc actions which arrangement is a sufficient step to democratization of the society and power institutions. Most part of the actions end up by informing and monitoring. The most effective and productive methods of interactions, i. e. shared decision-making and share decision implementation, tend to be ignored. Both public activists and officials seem to forget that the only source of power is people (Article 5, the Constitution of Ukraine). Citizens have to remember it and remind it to officers. According to the Constitution (Article 3), the State is accountable before a person for its operation. Its principle duty is to ensure human rights and freedoms.

As a member of Council of Europe since 1995, Ukraine took on the responsibility to respect European standards, in particular the ones pertaining to local and regional democracy, provisions of the European Charter of Local Self-Government, ratified in 1997, and its additional Protocol on the right of participation in the operation of a local selfgovernment body, ratified in 2014. Item 2 of Article 1 says: "The right to participate in the affairs of a local authority denotes the right to seek to determine or to influence the exercise of a local authority's powers and responsibilities" [14], and Item 2a of Article 2 emphasize that local power bodies are responsible for creating "procedures for involving people which may include consultative processes, local referendums and petitions and, where the local authority has many inhabitants and/or covers a large geographical area, measures to involve people at a level close to them".

Conclusions and recommendations. The Ukrainian law, along with and the international commitments and standards, lay a solid legal base for broad-scale participation of the civil society in not only symbolic events, but also in the agenda setting, decision-making and elaboration of conclusions on the action's results.

Only a system for shared decision making and implementation is able to guarantee observation of continuing and effective feedback between the human and the power, which is really capable to exercise rights, aspirations and free development of a human in a manner that fits a human rather than a bureaucrat. Free development of a human is the main resource and driving force for the sustainable (accelerated) development of the society.

Participatory technologies and relevant standards are well understood and widely employed in advanced countries in the process of PowerCommunity cooperation. The European standards for Power - Community cooperation in Ukraine are now implemented at the level of public councils established at government institutions [15]. The positive experience of this project allows for its application in other public organizations.

Prospects of further studies. The further studies are related with the need of creating the conditions for the complex development of the system for interactions of the state power with the civil society in Ukraine. Greatly important is practical implementation of the principles for Power-Community cooperation and analysis of its improvement practices. The cooperation can be more effective if the dialogue involves Business and socially oriented entrepreneurship, and the required trust between all the parties exists.

The scientific results presented in this article are obtained as part of the research work with the registration number 0118U006677, 01.01.201931.12.2022.

\section{References}

1. Semianovskyi, V. M. (2018). Partysypatyvne upravlinnia yak model upravlinnia terytorialnymy hromadamy [Participative Management as a model of management of territorial communities]. Statistika Ukrainy - Statistics of Ukraine, 1, 47-51 [in Ukrainian].

2. Uriadovyi portal. Yedynyi veb-portal orhaniv vykonavchoi vlady Ukrainy [Government portal. Official website]. жrer.:kmu.gov.ua. Retrieved from https://www.kmu.gov.ua/ua [in Ukrainian].

3. Ofitsiinyi sait Derzhavnoi sluzhby statystyky Ukrainy [Official web-site of the State Statistics Service of Ukraine]. wewre.ukrstat.gov.ua. Retrieved from http://www.ukrstat.gov.ua/ [in Ukrainian].

4. Official web-site of Eurostat. ec.europa.eu. Retrieved from https://ec.europa.eu/eurostat/

5. Pro derzhavnu sluzhbu: Zakon Ukrainy vid 10.12.2015 r. № 889-VIII, stanom na 01.01.2019 r. [On Civil Service. Law of Ukraine of December 10, 2015 № 889-VIII as of January 01, 2019]. zakon.rada.goz.ua. Retrieved from https://zakon.rada.gov.ua/laws/show/889-19 [in Ukrainian].

6. Kanavets, M. (2018). Suchasnyi stan i perspektyvy rozvytku hromadianskoho suspilstva v Ukraini ta vzaiemodii orhaniv derzhavnoi vlady z hromadskistiu [Current state and prospects of the civil society development in Ukraine and interactions of public authorities with the public]. Efektyonist derzhavnoho 
upravlinnia - Effectiveness of public administration, 2 (55), 1, 153-168. Retrieved from http://www. lvivacademy.com/vidavnitstvo_1/edu_55/fail/18.pdf [in Ukrainian].

7. Pokaznyky Yedynoho derzhavnoho reiestru pidpryiemstv ta orhanizatsii Ukrainy (IeDRPOU). Kilkist yurydychnykh osib za orhanizatsiino-pravovymy formamy hospodariuvannia [Indicators of the Unified State Register of Enterprises and Organizations of Ukraine (EDRPOU). Number of legal entities for organizational and legal forms of management.]. wwow.ukrstat.gov.ua. Retrieved from http://www.ukrstat.gov. ua/ [in Ukrainian].

8. Zakonodavstvo Ukrainy: Baza danykh. Informatsiino-poshukova systema [Legislation of Ukraine Database]. zakon4.rada.gov.ua. Retrieved from http://zakon4.rada.gov.ua/laws [in Ukrainian].

9. Arnstein, Sh. R. (1969). A Ladder of Citizen Participation. Journal of the American Institute of Planners, 35, 4, 216-224. Retrieved from http://lithgow-schmidt.dk/sherry-arnstein/ladder-of-citizen-participation. html

10. Mizhnarodna asotsiatsiia hromadskoi uchasti [International Association of Public Participation IAP2]. wrewoiap2.org.au. Retrieved from https://www.iap2.org.au/Home

11. Rowe, G., \& Frewer, L. (2005). A typology of public engagement mechanisms. Science, Technology \& Human Values, 30, 251-290. Retrieved from http://citeseerx.ist.psu.edu/viewdoc/download?doi=10.1.1.546. $7172 \&$ rep $=$ rep $1 \&$ type $=$ pdf

12. Sustainable Development Goals. Knowledge Platform. United Nations. sustainabledevelopment. un.org. Retrieved from https://sustainabledevelopment.un.org/topics

13. Zaiava pro Kodeks nalezhnoi praktyky uchasti hromadskosti u protsesi pryiniattia rishen: pryiniata 21.10.2009 r. na 1068 zasidanni Zastupnykiv Ministriv. Rada Yevropy, Komitet Ministriv [Statement on the Code of Good Practice of Public Participation in Decision-making, adopted on October 21, 2009 at 1068th Deputy Ministers' Meeting. Council of Europe, Committee of Ministers]. wcd.Council ofEurope.int. Retrieved from https://wcd.Council ofEurope.int/ViewDoc.jsp?id=1525009\&Site=CM [in Ukrainian].

14. Dodatkovyi protokol do Yevropeiskoi khartii mistsevoho samovriaduvannia pro pravo uchasti u spravakh mistsevoho orhanu vlady vid 16.11.2009 r.[Additional Protocol to the European Charter of Local Self-Government on the right to participate in the affairs of the local government of November 16, 2009]. zakon.rada.goz.ua. Retrieved from https://zakon.rada.gov.ua/laws/show/994_946 [in Ukrainian].

15. Systema vzaiemodii vlady ta hromady na osnovi yevropeiskykh standartiv. Portal Koordynatsiinoho komitetu hromadskykh rad Ukrainy [The system of power and community interaction based on European standards. Portal of the Coordinating Committee of Public Councils of Ukraine]. kkgrua.com. Retrieved from https://kkgrua.com/forum/gromadskist-ukraini/8-cystema-vzaiemodii-vlady-ta-hromady-na-osnoviievropeiskykh-standartiv [in Ukrainian].

\section{В. М. Семяновський,}

кандидат фізико-математичних наук, доцент,

доцент кафедри економіко-математичних дисциплін та інформаційних технологій,

Національна академія статистики, обліку та аудиту,

E-mail: vadimc@i.ua

ResearcherID: X-9595-2018,

ORCID: https://orcid.org/0000-0002-5363-6446

\section{Участь громадськості у державному та місцевому управлінні: принципи, статистика та європейський досвід для України}

Питання ефективної участі та співпраці громадянського суспільства і владних структур останнім часом стало однією з головних соціальних проблем у світі. Хоча теоретичні питання партисипативного управління (управління участі) вже добре розроблені й широко застосовуються, наприклад, у підприємницькій діяльності, співпраця влади і громади становить серйозну проблему в світі й в Україні особливо. Результативність співробітництва влади і громадянського суспільства пов'язана з сучасним станом обох сторін, якістю ї роботи та взаємною довірою між ними. Слід також враховувати, що ця проблема $є$ частиною проблематики трикутника влада - суспільство - бізнес і зазнає значного впливу зовнішнього середовища в умовах глобалізаційних процесів у світі.

В Україні слід враховувати те, що чинна система влади досі має відбитки радянщини, практично не відповідає сучасним реаліям, а її реформа наразі неефективна. Дані Державної служби статистики України показують величезну кількість чиновників місцевого самоврядування і державних чиновників, зібраних у галузеві структури. Громіздкий апарат державного управління спрямований на рішення проблем галузей економіки, а до соціальних проблем, тим більше до проблем конкретної людини, черга доходить тільки перед виборами. 
3 іншого боку, за даними Держстату, в Україні спостерігається велика різноманітність різних громадських організацій, але їх загальна кількість мала. За даними Євростату, кількісні та якісні характеристики розвитку громадянського суспільства в Україні значно відстають від європейських. За великої розмаїтості цілей має місце слабка консолідація зусиль, ресурсів і методів вирішення найбільш важливих проблем суспільства. Усе це сильно ускладнює співпрацю влади і громади.

Теоретичні та практичні аспекти проблеми співпраці структур влади і громадянського суспільства давно розробляються в Свропі. Ззапропоновані й упроваджені сучасні принципи та різні технології іï розв'язання. Висвітлено першу типологію громадської участі у вигляді “драбини громадянської участі”, розроблену американською дослідницею Ш. Р. Арнштайн. Вона виокремила три рівні - неучасть, символічна участь і громадська влада. Розглянуто Кодекс рекомендованих норм участі суспільства в прийнятті публічних рішень, розроблений для значного підвищення ефективності спільної діяльності Європейського Співтовариства. Ця технологія фактично є стандартом співпраці влади і громадянського суспільства в Європі.

У роботі обгрунтовано необхідність реформування системи співпраці владних структур та громадянського суспільства в Україні на основі використання європейського досвіду такої співпраці. Висвітлено цілі, принципи, методи й етапи співпраці влади і суспільства, проаналізовано їх переваги та недоліки. Зазначено, що таке співробітництво буде ефективнішим, якщо передбачатиме участь соціально орієнтованого підприємництва та формування довіри між усіма сторонами.

Ключові слова: органи державної влади, органи місцевого самоврядування, громадянське суспільство, інститути громадянського суспільства, партисипативне управління, співпраия, участь .

Bibliographic description for quoting:

Semianovskyi, V. M. (2019). Participation of the Public in State and Local Governance: Principles, Statistics and European Experience for Ukraine. Statystyka Ukrainy - Statistics of Ukraine, 2, 21-30. [in English]. Doi: 10.31767/su. 2(85)2019.02.03.

Бібліографічний опис для цитування:

Семяновський В. М. Участь громадськості у державному та місцевому управлінні: принципи, статистика та європейський досвід для України (публікується англійською мовою) // Статистика України. 2019. № 2. C. 21-30. Doi: 10.31767/su. 2(85)2019.02.03. 